\title{
Limitations in the Work of Polish Teachers: Report of Research
}

\author{
Aleksandra Chmielińska \\ University of Lodz, Poland \\ E-mail address: chmielinska@op.pl
}

\author{
Monika Modrzejewska-Świgulska \\ University of Lodz, Poland \\ E-mail address: modrzejewska@lodz.uni.pl
}

\section{ARTICLE INFO}

\section{Keywords:}

Limitations in teachers' work Limitations in innovation in schools State diagnosis

\section{Article history:}

Received 3 January 2014

Received in revised form 22 March 2014

Accepted 9 April 2014

ISSN:

\section{A B S TRACT}

\section{INTRODUCTION}

At the end of World War II, Poland found itself behind the so-called iron curtain and was governed by a communist regime; in other words, the Polish State was under the political, economic and strategic influence of the USSR. Between the years 1989 - 1991, as a result of political reforms, the State underwent a transformation into the democratic Republic of Poland. After 1989 an intensive socio-economic transformation began, which also affected Polish education. Reforms in education evoked optimistic emotions and hopes for real changes in the system of education at every level. Political and economic conditions began to be favourable in terms of the personal, social and professional autonomy of teachers and many educational innovations appeared, e.g. the school curriculum being protected by copyright programmes. There were hopes that alongside the new political system, the formal structure of school organisation would also change and - more importantly - that changes would also occur in the mentality, not only of teachers, but in particular of the educational authorities. After over twenty years of successive reforms, changes in education and education authorities, it is worth looking into what is left of the

\footnotetext{
${ }^{1}$ As a context for our state diagnosis it is worth quoting research carried out in May 2013 by the Public Opinion Research Centre in Warsaw entitled: "Current problems and events" (276), on a representative random sample of 1101 adult inhabitants of Poland. The results demonstrated that there is a feeling of missed historical opportunities amongst the Poles, opportunities that were connected with the transformation - the majority (59\%), of respondents claim that more could have been done (Research statement. Was it worth changing the system? Social evaluation of the changes after 1989. BS/73/2013. CBOS).
} 
optimistic approach that followed the year $1989 .{ }^{1}$ It is important to know and understand current views that define school reality and not only those declared in official documents, and reports, so as to plan real and new changes in education (Drucker, 1993).

During our work with teachers (workshops, lectures, methodological consultations, individual and team coaching) our particular attention has been drawn to the image of schools emerging from their statements as being 'superficially innovative'. We define the term 'innovation' as introducing creative ideas (new and useful) into practice, including that of the school context. We treat the term somewhat broadly, understanding it as referring not only to the creation of new ideas, things, goods or services, but also as social solutions that foster quality of life and work (West \& Ricards, 1999; West, 2000; Szmidt, 2013).

What we have in mind is that the problems and difficulties experienced by teachers and voiced during meetings are typical limitations for innovative thinking at every level of an organisation's functioning. We wonder whether innovations in Polish schools are of a systemic character or exclusively educational and instructive. We are convinced that educational innovations should not be treated solely as activities that are subjective, but also organisational and systemic because innovativeness is not just the matter of an individual teacher, but of the whole school community. Educational innovation understood in this way may trigger changes in the closest environment of a school or local community (see Drucker, 1992; Przyborowska 2013).

However, innovative activities require a particular atmosphere. According to authors undertaking research into the atmosphere fostering innovation, there are elements in organisations that do promote the implementation of new / unorthodox ideas. These include, e.g. the support of others, supervisors in particular, safety, clear goals, flexible procedures, creative leadership, debates, appropriate communication on every level of the organisation, co-operation, possibilities for experimentation, the consent for risk-taking and making mistakes, creative activities (Isaksen, Lauer, Ekvall, Britz, 2001; Karwowski, 2009; West, 2000). On the other hand, they list numerous barriers that influence the outcomes of innovative activities. Some of the most frequent obstacles in organizations, that make it difficult for innovative ideas to be implemented, are administrative and financial concerns (e.g. an inappropriate system of bonuses), limitations (e.g. the imposition of subject material, expectations regarding behaviour, work methods no interest in innovative solutions, inappropriate human resources management, excessive criticism from superiors, unrealistic expectations, lack of feedback, insufficient resources (e.g. funding, incompetent co-workers), time pressure; rivalry between departments/people (Adams, 
1986; Von Oech, 1983; Amabile, 1996; Davis, 2004). Thus, we tentatively defined the term limitation (barrier) as factors influencing the undertaking, course and outcomes of innovative activities.

\section{METHODS AND RESEARCH CONTEXT}

The research presented was conducted as part of a project entitled "System of school support in the Kartuzy district" (funded by the European Social Fund). Holistic diagnosis of school reality was based on analysis of the school environment and its functioning, on the basis of teachers' opinions (their subjective experiences). ${ }^{2}$ It was carried out by scientific workers and coaches (the authors of this article) during diagnostic workshops in which teachers participated.

The educational project "System of school support in the Kartuzy district" is aimed at recognising the specific properties of school reality in the Kartuzy district through multifaceted diagnosis and, as a result, increasing teachers' skills (supporting teachers' professionalism). The beneficiaries of the project are teachers, educators, school counsellors and school headmasters. The project is monitored by the Starost of the Kartuzy Poviat in co-operation with The Centre of Education Initiatives in Kartuzy. ${ }^{3}$

Realisation of the project is possible thanks to the complex activities undertaken by the following specialists and institutions: The Department of Education of the Starost of the Kartuzy Poviat (substantive co-ordinator), The Centre of Education Initiatives in Kartuzy (substantive and programme co-ordinator), The Teacher Education Centre in Gdańsk and the University of Gdańsk (substantive support), six School Education Development Organisations (SORE [PI] / SEDO [Engl] ${ }^{4}$ ); two external experts: trainers / coaches - diagnosing the school situation of each individual institution (the authors of the text); specialists in selected issues in psychology, didactics, methodology, therapy and law (Dereń, 2014) .

Consecutive stages of the project included:

\section{Level of diagnosis:}

a. Holistic diagnosis, carried out on the basis of diagnostic and developmental skills during which a given school reality is analysed. Factors belonging to this section are:

\footnotetext{
${ }^{2}$ The term diagnostics is understood by us as the cognitive process of exploration of a given social reality, using various instruments (discussions, diagnostic tools, document analysis), which is intended to lead to forming development plans and support for a given social institution (e.g. school).

${ }^{3}$ The duties of the Centre include, e.g. organising classes supporting the development of children and teenagers, realising projects and educational programmes. Activities of the $\mathrm{CIE}$ are evolving around cultural education and are creating a coherent system of school support realised through actions that allow co-operation among students and teachers, meetings with masters and experts that are an integral part of the cultural aspect of education.

${ }^{4}$ SORE/SEDO is a type of school counsellor, a trainer, a person from outside who supports the development of a school by offering help in analysing the school's needs, selecting appropriate workshops from the rich list of education courses. Such a person is also to create an ASP (Annual Support Plan) which describes the duties of a headmaster, teachers' board (TB), task team in detail, listing the number of hours, dates, forms, etc.
} 
educational facts and events; activities; teachers' own behaviour; intra-school communication: between teachers, teachers/headmaster, teachers/students; communication outside school: teachers/parents; school/local community. This stage is realised by the experts on diagnosis, using coaching diagnostic instruments (the authors of the text).

b. Drawing up a School Annual Support Plan (SASP) on the basis of holistic diagnosis delivered by the experts (the authors of the text). The plan is prepared by SEDO in co-operation with the school pedagogical team.

\section{Level of change:}

a. Improving a teacher's work on the basis of SASP and using various forms of support such as workshops, psychological training, lectures, group and individual consultations, group and individual coaching (e.g. headmaster's). Realisation of this stage is the duty of external experts (team coaches, psychologists, educators, psychotherapists, subject methodologists) within the chosen subject adjusted to the needs of an individual school, the object of activities being educational practice. The authors of the text are among the group of listed specialists.

b. Preparing a SASP realisation report together with recommendations for further work in the consecutive school year (in the 2nd edition of the project), during which evaluation of the 1 st part of the project achievements will also take place.

\section{Research participants}

42 schools were included in the diagnosis (16 secondary schools, 24 elementary schools and 2 kindergartens), which is around $39 \%$ of all schools in the Kartuzy Poviat, and the direct recipients of the project were 766 teachers. Diagnostic activities were realised during individual meetings with school headmasters and several hour long diagnostic and development workshops with groups of teachers (overall there were meetings with 766 teachers). Meetings were held in the absence of the management personnel. We did not want team work, the issues tackled, and the difficulties and problems postulated to be influenced by the presence of headmasters on each occasion, the needs analysis was aimed at pointing to areas of change which a team from a given school wished to explore in further parts of the project.

\section{Research instrument}

For the purposes of the diagnostic procedures, we used the following: the ICC $^{5}$ diagnostic coaching instruments - Goal Grid in order to structure group and individual discussions with teachers and headmasters. Goal Grid includes the following areas of analysis:

1. Resources - defined as important and valuable aspects of work that the pedagogical

\footnotetext{
${ }^{5}$ ICC - International Coaching Community is one of the biggest professional organisations for coaches in the world. One of the authors is a member of the ICC.
} 
team wishes to maintain. The area was diagnosed through two questions: What do we want? and What do we have?

2. Matters to be eliminated - areas and problems that the pedagogical team treats as unwanted. The area was diagnosed through two questions: What don't we want? and What do we already have?

3. Motivators - defined as areas and aspects of work that the team wishes to achieve and develop in their school in future. The area was diagnosed through two questions: What do we want? and What don't we have?

4. Concerns - defined as those aspects that may interfere with future work of the pedagogical team and ones that the team wishes to avoid. The area was diagnosed through two questions: What don't we want? and What don't we have? (Chmielińska, Modrzejewska-Świgulska, 2014).

Diagnosis was begun with a group discussion centred around the following outline: Our school and us as a teaching team. The work was monitored by two coaches (the authors of the research) -we took notes during the group discussion and whenever possible, recorded, took pictures, collected the teachers' notes. Adopting team coaching assumptions (Clutterbuck, 2007; Mackin, 2007), our task was neither to prepare a strategy nor point to ready solutions, but to accompany the participants in the process of analysis of the most important needs and problems their school faced with the use of appropriately selected methods of team work.

\section{Procedure for the interpretation of the research material}

We only analysed in detail data concerning the second area of the diagnosis (of the four described above), that is, matters to be eliminated (difficulties and problems at school) that were acknowledged by the participants of the diagnostic workshops.

While interpreting the written statements of the teachers, we asked ourselves the following question: What image of the school emerges from these statements? Analysis and interpretation of data was of an inductive character and was carried out in several stages. In the first stage of our analysis, we distinguished 30 common threads in the written statements of the teachers concerning matters to be eliminated. Subsequently, the 30 areas obtained were reduced to 20 and we named them according to detailed categories that at the same time were the properties of 8 basic categories. These parent categories were made up of 4 general ones that describe the central category of the teachers' statements - limitations affecting teachers' work (Table 1). 


\section{RESULTS OF RESEARCH - LIMITATIONS IN INNOVATIVE APPROACH IN THE EXPERIENCE OF POLISH TEACHERS}

As can be seen from our diagnostic research, barriers affecting teachers' work mostly concerned individual competences (those of teachers, school management personnel), ability to communicate well and efficiently, creative leadership. Additionally, the lack of flexible procedures (the legal and economic context of the school's operating system) was identified as significantly hindering innovations to the system, at an organisational level (compare cf. Isaksen, Lauer, Ekvall, Britz, 2001; West, 2000; 2002; Karwowski, 2009). Below, we present a hierarchical dependency of the theoretical categories elicited (Table 1) and describe selected limitations (blocking innovative activity) in detail: ${ }^{6}$

\section{TABLE 1}

\section{Limitations affecting Polish teachers' work - hierarchy of categories}

\begin{tabular}{|c|c|}
\hline \multicolumn{2}{|c|}{ Central category - limitations affecting teaches' work } \\
\hline Basic categories (8) & Properties / attributes of detailed categories (20) \\
\hline \multicolumn{2}{|r|}{ General category - individual limitations } \\
\hline $\begin{array}{l}\text { 1. Individual limitations } \\
\text { affecting teachers }\end{array}$ & $\begin{array}{l}\text { 1. Psychological difficulties affecting teachers' work } \\
\text { 2. Teachers' attitudes towards work and organisation of work } \\
\text { 3. Professional development } \\
\text { 4. Rules governing teacher - student relationships } \\
\text { 5. Teachers' availability and additional duties at work } \\
\text { 6. Effects of teaching }\end{array}$ \\
\hline $\begin{array}{l}\text { 2. Co-operation in peda- } \\
\text { gogical teams } \\
\text { 3. Leadership at school }\end{array}$ & $\begin{array}{l}\text { 7. Relationships between teachers } \\
\text { 8. Teachers' co-operation } \\
\text { 9. Leader - teacher relationship } \\
\text { 10. School management }\end{array}$ \\
\hline $\begin{array}{l}\text { 4. Students and their in- } \\
\text { fluence on the life of the } \\
\text { school }\end{array}$ & 11. Students' attitudes towards school and educational problems \\
\hline
\end{tabular}

General category - limitations within the local community

\begin{tabular}{ll}
\hline 6. School partners and co & 12. The school and decision making bodies \\
-operation with them & 13. Co-operation with parents \\
& 14. Co-operation with the local community \\
& 15. Social opinion about the school and teachers
\end{tabular}

\section{General category - limitations connected with the premises}

\section{Working environment 16. Organisation of work at school} of teachers

17. Premises and school equipment

\section{General category - limitations connected with the cultural context} of the school's work
8. Legal and economic
18. Situation on the labour market context of the school's work
19. Educational reforms, changes
20. Bureaucracy

\footnotetext{
${ }^{6}$ Data used in the article from part of a report available in the evaluation materials and documents within a project entitled: "System of school support in the Kartuzy district". Materials were prepared and are distributed free of charge by the co-ordinator: The Centre of Education Initiatives in Kartuzy to the beneficiaries and implementers of the programme. The report was prepared by the authors of this article (Chmielińska, Modrzejewska-Świgulska, 2014).
} 
The teacher as a subject of creative activities (Table 1) - this refers to teachers' individual areas of work, including their sense of self-efficacy and self-fulfilment at work. ${ }^{7}$

a. Psychological difficulties affecting teachers' work were reported and these were mostly issues concerning professional burnout, stress at work, and insufficient openness and / or fear of the new / innovations being introduced into teachers' work. These problems are illustrated in the following examples of personal difficulties described in relation to pedagogical work: stress concerning the introduction of innovations, education (stress connected with family conflicts, psychological distress); professional burnout (psychological fatigue, no desire or energy to undertake activities); sense of helplessness - disparity between the effort put into teaching and students' progress.

$b$. Teachers' attitudes towards work and organisation of work refers to the extent of personal engagement and concern for the high quality of teaching and education, and systematic delivery of the educational activities undertaken. This is illustrated by the following examples: the passive attitudes of teachers; professional routine; mediocrity and chaos in carrying out duties; lack of a systematic approach in executing rules to maintain standards of students' behaviour.

c. Professional development appears as a factor that hinders teachers' work in the form of "overtraining syndrome". Teachers participate in numerous forms of training on various subjects; however, they treat them as a formality and do not introduce the developed effects into their own work. The following statements illustrate this point: too many training requirements; useless and senseless forms regarding training; pressure to participate in training; unnecessary training (inappropriate subject, not adjusted to appropriate levels).

Pedagogical team and work quality (Table 1) - this category includes the area of building interpersonal relations and the ability to work in a team.

a. Relations between teachers are listed as an issue in schools; they mostly include disruptions at the level of a team's maturity, verbal communication, assertive building of relations, ability to delegate professional and collegial duties at work, and ethical aspects of work in a team. The following quotes illustrate this point: no group solidarity and consensus; dishonesty and superficial contacts; no courage in talking about difficult problems in a team; no support from colleagues when talking about difficult problems; obstinacy; egoism; no tolerance in teachers' team; no openness and honesty in teachers' team; non-compliance of teachers to the basic rules of ethics in relations (no respect).

\footnotetext{
${ }^{7}$ We have italicised quotes from the written statements of teachers.
} 
b. Inappropriate co-operation among teachers is a factor disrupting the team's work in schools. The listed difficulties mainly concern solving conflicts, group work planning and setting goals, credibility and trust in a team, engagement in team work and taking responsibility for tasks. Examples of lack of competences in the above areas listed by the teachers include:

"lack of responsibility among team members as far as realising tasks assigned to them is concerned and ignoring the assigned tasks (running away from responsibilities); lack of engagement among all teachers; no solidarity, lack of regularity; no consequence in activities regarding realisation of teachers' board provisions; little ability to work out specific solutions to problems during team meetings (a lot of talking, few specifics, waste of time on empty discussions followed by nothing); no discipline among the teachers' board during their meetings."

Leadership at school (Table 1) - the leadership category appeared in educators' narrations in relation to building relations between teachers and a school's headmaster. However, for the vast majority, this field is connected with school management.

a. When it comes to leader - teacher relationships, the main problem is in relation to schools' headmasters treating a teacher as an individual in relation to the following activities: imposing activities without prior consultation with the teacher; requiring participation in tasks and workshops without informing the teaching team earlier; teachers having no influence on decisions concerning the team.

$b$. The issue of school management appeared in the diagnoses of the schools and was most frequently defined as lack of trust and respect between the management and the team; insufficient information flow from the management to the teachers; little or no support from the management; an ordering management style and no key competences in working with the team, such as delegating responsibilities or providing feedback. These problems were exemplified by teachers as follows:

"the head teacher's interference and pressure on teachers and decisions made by them; the failure to solve team problems together with the head; poor information flow between headmaster and teachers; changeability of the head teacher in relation to previously taken decisions and activities planned earlier; uneven and unfair treatment of teachers; no sense of appreciation from the management (only outcome counts and not effort put into achieving it); no understanding of the direction for the development of the school amongst the teachers; imposing the role of team leader by the management."

Legal and economic context of a teacher's work (Table 1) - this category concerns 
teachers' comments on educational reforms, the situation on the labour market and above all, limitations resulting from bureaucracy.

a. Teachers commented on the negative outcomes of constant administrative and legal changes concerning: the requirements made on teachers, changes in curriculum, textbooks or set books. In their discussions, teachers emphasised mainly: changes in curriculum; increases in the number of hours; no legal stability (permanent changes in law, e.g. retirement age, annual changes in set books or textbooks).

b. The unstable situation on the labour market as a matter to be eliminated was brought up in discussion in just one team.

Bureaucracy (no flexible system of education regulations) is a barrier to work that was widely commented on by teachers. This category includes the necessity for generating documents that is not understood and is unnecessary to the work of teachers (e.g. schedules, reports concerning project realisation, drafts, justifications for programme selection; programmes describing incidental events such as an hour-long excursion to a nearby park mid-semester, half-year and annual class statistics). Teachers emphasised the mismatch in the requirements and decisions made by administrative staff in relation to the real conditions at school and in educational work; lack of regulations pertaining to exceptional cases that would apply under these circumstances as comparedto those specified in the standard Acts and ordinances. Teachers postulated that too much bureaucracy makes it impossible for them to carry out their basic duties, i.e. teaching. In summary, it may be said that the reported problems can be described as a transfer of the goals typical for a school onto activities superficially connected with the necessity for generating documents, that for decision making bodies have become more important than the real work of a teacher and student with his/her individual 'story'. The following statements illustrate this point:

"frequent controls from bodies supervising schools during which documents and regulations have become more important than realising the goals for which a school exists; teachers' real work does not count any more, neither does a student with his particular story in terms of the examination results."

\section{DISCUSSION}

We treat the results as a stimulus and introduction to further inquiries in the area of innovation and the subjective conditions and socio-economic factors which influence this process. In the statements of teachers, headmasters and decision makers we see certain significant limitations to innovativeness that are connected with the rigid, formal structure of schools, communication barriers that disrupt co-operation within teaching teams and 
the local community (local institutions, other schools and mostly with parents).

The most important conclusions relisted below in several points that concern not only suggested corrective actions on the level of individual competences, but also in a more general reflection connected with the operation of the socio-cultural school system:

From the comments of the participants it may be concluded that a significant barrier to their professional work exists in the form of limitations connected with bureaucracy, which make it harder for them to realise their educational and teaching activities. Thus, we wonder to what extent it is possible to introduce innovativeness (atypical, creative tasks) that require re-structuring of the existing socio-cultural school system, since it is known that limitations connected with bureaucracy not included in the regulations, block the smooth operation of schools. We assume that real, innovative concepts introduced to schools mostly concern isolated methodological and educational activities and not the school system as a whole. The concept of innovativeness in schools requires deeper thought and mutual discussions among the scholars and practitioners, and representatives of the educational system. Diagnosis of the current state confirmed the following barriers to innovativeness in schools described in the literature, including: the contradictory interests of the various social groups engaged in education; lack of co-operation between local educational and cultural institutions; too many petty and insignificant legal changes; underinvestment in education; ambiguity of school tasks; insignificant influences from the surrounding environment; parents; a lack of leaders who would efficiently manage institutions; lack of effective and multi-level communication and no co-operation as a result of this (Przyborowska, 2013).

A significant factor for change and effective group co-operation is a leader, his personality and ability to build a team and partnerships. We believe that a creative leader is indispensable to a school (creative leadership) as compared to a headmaster who is merely in a supervisory role. One of the greatest limitations to a teacher's work that was highlighted during the research meetings, was the management style of the teaching team. Our diagnosis revealed the necessity for supporting the leadership competences of headmasters and their particular skills: being able to communicate with a team, building a team, inspiring and motivating verbally and through example, triggering creative energy in a team, knowing the methods and techniques for solving problems, appreciating efforts and providing fair rewards for efforts undertaken (Adair, 2008; Puccio, Mance, Murdock, 2011).

Discussions with teachers confirmed our previous conviction concerning the necessity for changes at the level of individual competences, especially those concerning the 
ability to communicate well. Appropriate and supportive communication is the basic condition for effective co-operation and even more so with regard to innovative activities at every level of the school system: teacher - teacher, teacher - student, teacher - management, school - local educational cultural institutions, school - supervising bodies. By means of proper communication we understand a dialogue that would not only be an argumentative duel, but a conscious competence in listening to others and holding a conversation, an element of a teacher's job and thus a desired aspect of a teacher's professionalism. Close to our belief is what Richard Sennetti (2013), a sociologist dealing with analysis of the public sphere described, in claiming that co-operation is a job and we need to learn it again, because the transformations of the contemporary work system, jeopardise this ability, deeply rooted in human nature.

\section{REFERENCES}

Adams, J. (1986). Conceptual block busting: A guide to better ideas, New York: Perseus Book.

Adair, J. (with Peter Reed) (2008). Od bossa do lidera. Prowadzić innych do sukcesu, Kraków: Oficyna Wolters Kluwer Business.

Amabile, T. A (1996). Creativity in context. Update to the social psychology of creativity, Boulder: Westview Press.

Clutterbuck, D. (2007). Coaching The Team At Work. Boston: Nicholas Brealey International.

Chmielińska, A., Modrzejewska-Świgulska, M. (2014). Diagnoza stanu, czyli nauczyciele o sobie $i$ swojej pracy. Krótki raport z badań. In A. Dereń (Ed.), System wspierania szkół w powiecie kartuskim. Projekt współfinansowany przez unię Europejska w ramach Europejskiego Funduszu Społecznego. Kartuzy: Centrum Inicjatyw Edukacyjnych, (evaluation materials and documents within the project entailed: "System of school support in the Kartuzy district").

Davis, G. A. (2004). Creativity is forever, Dubuque-lowa: Kendall/Hunt Publishing Company.

Dereń, A. (2014). System wspierania rozwoju szkół w powiecie kartuskim. In A. Dereń (Ed.), System wspierania szkół w powiecie kartuskim. Projekt współfinansowany przez Unię Europejską w ramach Europejskiego Funduszu Społecznego. Kartuzy: Centrum Inicjatyw Edukacyjnych.

Drucker, P. F. (1992). Innowacja i przedsiębiorczość. Praktyka i zasady, Warszawa: PWE. Drucker, P. F. (1993), Post-capitalist society, Oxford: Butterworth-Heinemann. 
Isaksen, S. G., Lauer, K., Ekvall, G., Britz, A. (2001), Perceptions of the best and worst climates for creativity: Preliminary validation evidence for the Situational Outlook Questionnaire. Creativity Research Journal, 2, 171 - 184.

Przyborowska, B. (2013). Pedagogika innowacyjności. Między teorią a praktyką. Toruń: Wydawnictwo Naukowe Uniwersytetu Mikołaja Kopernika.

Karwowski, M. (2009). Klimat dla kreatywności. Koncepcje, metody, badania. Warszawa: Centrum Doradztwa i Informacji Difin sp.z 0.o..

Mackin, D. (2007), The Team Building Tool Kit: Tips and Tactics for Effective Workplace Teams. New York: Amacom.

Puccio G. J., Mance M., Murdock, M. C. (2011). Creative Leadership. Skills That Drive Changes, Printed in United States of America: SAGE Publications, Inc.

Sennett, R. (2013). Razem. Rytuały, zalety i zasady współpracy. Warszawa: Warszawskie Wydawnictwo Literackie MUZA S.A.

Szmidt, K. J. (2013). Pedagogika twórczości. Sopot: Gdańskie Wydawnictwo Psychologiczne.

Von Oech, R. (1983). A wack on the side of the head. New York: Warner Communications.

West, M. A., Ricards T. (1999). Innowation, In M. A. Runco, S. R. Pritzker (Eds.) Encyclopedia of creativity, San Diego: Academic Press.

West, M. A. (2000). Rozwijanie kreatywności wewnątrz organizacji, Warszawa: Wydawnictwo Naukowe PWN.

West, M. A. (2002). Sparkling foundations or stagnant ponds: An integrative model of creativity and innovation implementation in work group. Applied Psychology: An International Review, 51, 355 - 424.

Corresponding author at: Monika Modrzejewska-Świgulska, Faculty of Educational Scences, University of Lodz, 46/48 Pomorska St., 91-408 Lodz, Poland. E-mail: modrzejewska@lodz.uni.pl

Corresponding author at: Aleksandra Chmielińska, Faculty of Educational Scences, University of Lodz, 46/48 Pomorska St., 91-408 Lodz, Poland. E-mail: chmielinska@op.pl 